\title{
POLA LUKA PADA KEMATIAN AKIBAT KEKERASAN TAJAM DI BAGIAN ILMU KEDOKTERAN FORENSIK DAN MEDIKOLEGAL RSUP PROF. DR. R. D. KANDOU MANADO PERIODE 2013
}

\author{
${ }^{1}$ Erlando Nerchan \\ ${ }^{2}$ Johannis F. Mallo \\ ${ }^{2}$ Nola T. S. Mallo
${ }^{1}$ Kandidat Skripsi Fakultas Kedokteran Universitas Sam Ratulangi Manado
${ }^{2}$ Bagian Ilmu Kedokteran Forensik dan Medikolegal RSUP Prof. Dr. R. D. Kandou Manado
Email: enerchan@yahoo.com

\begin{abstract}
Wounds caused by a sharp trauma is an injury caused by sharp or pointed edged instruments. There are three types of wounds: stabbed, sliced, and chopped. This study aimed to determine the pattern of injuries in dead cases due to sharp trauma at the Department of Forensic Medicine and Medicolegal Prof. Dr. R. D. Kandou Hospital Manado. This was a descriptive retrospective study using the results of visum et repertum. The results showed that the percentages of wounds leading to the death were: $89 \%$ stabbed wounds, $5 \%$ sliced wounds, and 6\% chopped wounds. Most victims were at the age group of 20-30 years, followed by the age group of 30-40 years, 40-50 years, and 50-60 years.
\end{abstract}

Keywords: wound patterns, sharp violence

\begin{abstract}
Abstrak: Luka akibat kekerasan tajam adalah kelainan pada tubuh yang disebabkan karena tertusuk atau tergores dengan benda atau alat yang bermata tajam atau berujung runcing. Luka akibat kekerasan tajam terbagi atas tiga, yakni luka tusuk, luka iris dan luka bacok. Penelitian ini bertujuan untuk mengetahui pola luka pada kematian akibat kekerasan tajam di Bagian Ilmu Kedokteran Forensik dan Medikolegal RSUP. Prof. Dr. R. D. Kandou Manado. Penelitian ini bersifat deskriptif retrospektif dengan mengambil data sekunder dari hasil visum et repertum. Dari hasil penelitian dapat diperoleh persentase luka yang menyebabkan kematian yakni: luka tusuk 89\%, luka iris 5\%, dan luka bacok 6\%. Distribusi umur korban kematian umumnya dari kalangan muda 20-30 tahun, diikuti oleh kelompok umur 30-40 tahun, umur 40-50 tahun, dan umur 50-60 tahun.
\end{abstract}

Kata kunci: pola luka, kekerasan tajam

Aksi kekerasan dengan menggunakan senjata tajam (sajam) masih marak ditemukan di Kota Manado. Data yang diperoleh pada semester satu tahun 2014 ini terdapat sebanyak 73 laporan kekerasan tajam masuk di Polresta Manado. Masalah ini masih menjadi topik perbincangan yang hangat diseluruh lapisan masyarakat. Kekerasan seringkali menjadi bagian dari sebuah perselisihan. Perilaku kekerasan sering menimbulkan bahaya bagi individu itu sendiri maupun orang lain. ${ }^{1-3}$

Rata-rata kasus setiap bulannya di atas 200 laporan. Kasus penganiayaan berat di awal tahun masih tergolong rendah. Namun, memasuki bulan Maret hingga bulan Juni kasus ini mulai marak terjadi. Sepanjang semester satu tahun 2014 kasus kekerasan tajam cukup menunjukkan peningkatan. ${ }^{4}$ Data yang diperoleh dari Polresta Manado pada tahun 2013 yaitu sebanyak 25 kasus kekerasan tajam yang 
dilaporkan dan semuanya telah terselesaikan. Juga diperoleh data sebanyak 56 kasus sajam sepanjang bulan Januari 2012 sampai Oktober 2013, yang meliputi pengania-yaan, pembunuhan, atau sekedar membawa barang tersebut. ${ }^{5}$

Ditinjau dari sifat kekerasan, kekerasan tajam merupakan kekerasan yang seringkali dilakukan dengan menggunakan bendabenda tajam seperti pisau, kapak, silet, dll. Benda-benda ini dapat mengakibatkan luka bagi individu yang terlibat dalam proses kekerasan ini. $^{1}$

Luka akibat kekerasan tajam dapat berupa: luka tusuk, luka iris, dan luka bacok. Ditinjau dari aspek medikolegal pemeriksaan terhadap orang yang menderita luka akibat kekerasan, pada hakekatnya dokter diwajibkan untuk dapat memberikan kejelasan dari permasalahan seperti jenis luka yang terjadi, jenis kekerasan atau senjata yang menyebabkan luka, dan kualifikasi luka. ${ }^{1}$

Penelitian ini diharapkan dapat membantu para ahli medis, para penegak hukum dan oknum-oknum terkait dalam penyidikan kasus kekerasan tajam.

\section{METODE PENELITIAN}

Penelitian ini merupakan penelitian deskriptif restrospektif dengan mengambil data sekunder dari hasil Visum et Repertum di RSUP Prof. DR. R. D Kandou Manado periode 2013.

Populasi target ialah seluruh kasus kekerasan tajam di Kota Manado. Populasi terjangkau ialah seluruh kekerasan tajam pada kematian di Bagian Ilmu Kedokteran Forensik dan Medikolegal RSUP Prof. Dr. R. D. Kandou Manado.

Sampel penelitian ialah total populasi terjangkau periode Januari 2013-Desember 2013. Variabel penelitian ialah jumlah kasus, jenis kelamin, umur, jenis kekerasan tajam, pola luka, dan lokasi luka.

\section{HASIL PENELITIAN DAN BAHASAN}

Penelitian deskriptif retrospektif mengenai pola luka pada kematian akibat kekerasan tajam dilakukan di Bagian Ilmu kedokteran Forensik dan Medikolegal RSUP Prof. Dr. R. D. Kandou Manado periode Januari 2013-Desember 2013.

Tabel 1. Jumlah korban kematian berdasarkan umur

\begin{tabular}{cc}
\hline Umur & Jumlah korban \\
\hline 20 & 2 \\
22 & 1 \\
28 & 1 \\
31 & 1 \\
37 & 1 \\
48 & 1 \\
56 & 1 \\
59 & 1 \\
\hline
\end{tabular}

Dari seluruh data yang didapatkan sebanyak 13 kasus kekerasan tajam yang ada di Bagian Ilmu Kedokteran Forensik dan Medikolegal RSUP. Prof. Dr. R. D. Kandou Manado 25 kasus yang dilaporkan di Polda Manado, dan hanya terdapat sebanyak 9 kasus yang masuk dalam kriteria inklusi yakni kasus kekerasan tajam pada korban yang mati. Dari data sampel yang di peroleh dari Visum et Repertum dapat diperoleh berbagai data seperti identitas, umur, jenis luka akibat kekerasan tajam, lokasi luka dan sebab kematian korban.

Dari 9 visum yang didapatkan, diperoleh data sebanyak 88 orang laki-laki dan 1 orang perempuan dengan persentase kematian korban sebanyak 88,9\% untuk korban laki-laki dan 11,1\% untuk korban perempuan.

Korban kematian akibat kekerasan tajam dalam penelitian ini didominasi oleh kelompok umur 20-30 tahun sebanyak 4 kasus, terutama untuk umur 20 tahun didapatkan sebanyak 2 kasus, umur 22 tahun dan 28 tahun masing-masing 1 kasus. Diikuti kelompok umur 30-40 tahun sebanyak 2 kasus, umur 31 tahun dan 37 tahun masing-masing 1 kasus. Untuk kelompok umur 40-50 tahun sebanyak 1 kasus, yakni korban berumur 48 tahun. Yang terakhir ialah kelompok umur 50-60 tahun sebanyak 2 kasus, umur 56 tahun dan 59 tahun masing-masing 1 kasus. 
Jenis luka yang terjadi akibat kekerasan tajam yakni: luka tusuk, luka iris, dan luka bacok. Luka tusuk memiliki persentase tertinggi sebanyak $88,9 \%$ dari total keseluruhan kasus. Beberapa luka tusuk ditemukan pada satu korban akibat kekerasan tajam. Luka iris ditemukan sebanyak 5,55\% dan luka bacok sebanyak 5,55\% dari total keseluruhan kasus.

Luka akibat kekerasan tajam yang didapatkan kebanyakan pada bagian dada kiri $(17,1 \%)$ yang menembus sampai selasela iga, jantung, dan paru. Hal ini menggambarkan luka akibat kekerasan tajam yang terjadi lebih gampang menyebabkan kematian pada korban terutama luka tusuk (88,9\%). Luka tusuk yang ada biasanya sampai melubangi jantung $(7,31 \%)$ dan paru $(4,87 \%)$ korban. Luka tusuk yang ada memberi gambaran tepi luka rata dengan sudut yang tajam atau runcing.

Persentase untuk luka akibat kekerasan tajam pada bagian kepala kanan, wajah kanan, pipi kiri, bibir kanan, telinga kanan, leher kiri, puncak bahu, dada kanan, jarijari tangan kanan, perut kiri, punggung kiri, sela iga ke-3, sela iga ke-4, sela iga ke-6, sela iga ke-7, sela iga ke-8 dan tungkai masing-masing sebanyak 1 kasus (2,43\%). Pada bagian leher kanan, punggung kanan, dan perut kanan masing-masing 2 kasus (4,87\%). Pada bagian lengan kiri sebanyak 4 kasus (9,75\%) (Gambar 1). Luka pada lengan memiliki persentase tinggi diantara seluruh bagian yang mengalami luka; hal ini memberi gambaran bahwa korban menggunakan lengannya untuk menangkis serangan yang diberikan. Untuk luka iris dan luka bacok ditemukan masing-masing 1 kasus. Petunjuk dari luka tusuk sering dianggap sebagai suatu masalah pembunuhan terutama dalam persidangan, yang mengarah pada rekonstruksi pengadilan.
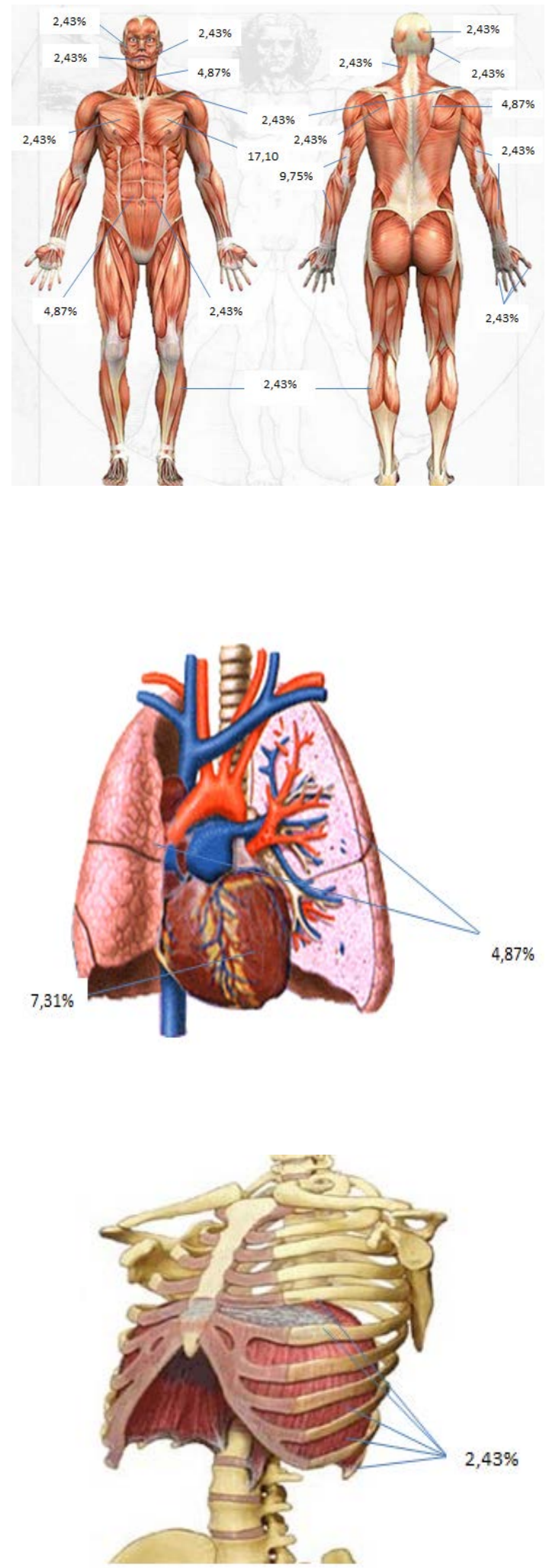

Gambar 1. Persentase letak luka pada korban kematian akibat kekerasan tajam 
Perkiraan derajat pada luka tusuk, diberikan keterangan sesuai dengan: ${ }^{6-8}$

1. Bagian dari tulang atau pengerasan tulang rawan

2. Ketajaman dari ujung pisau

3. Kecepatan datangnya pisau

4. Kulit yang elastis lebih mudah ditembus

5. Variasi ketebalan kulit terhadap pisau, kulit telapak kaki lebih tebal dari bagian tubuh lain

6. Luka tembus yang disebabkan tusukan

Kasus pembunuhan yang ditemukan seringkali bukan hanya terdapat satu luka tusuk saja, melainkan beberapa jumlah luka sekaligus. Luka tusuk yang hanya sekali saja dilakukan biasanya terdapat pada korban yang lemah atau tertidur saat terjadi serangan atau secara tiba-tiba bila korban terkenaa serangan di sekitar organ-organ vital. $^{9} \quad$ Luka-luka tusuk pada kasus pembunuhan yang dilakukan dengan menggunakan pisau lebih banyak ditemukan pada laki-laki dibandingkan perempuan. $^{10}$

Luka yang mematikan biasanya pada daerah leher, dada, dan pada daerah perut yang merupakan letak organ-organ vital. Luka tusuk pada dada bisa melibatkan jantung yang menyebabkan trauma pada miokardium, arteri koroner, struktur katup atau pembuluh darah besar, yang bisa mendatangkan ancaman nyawa bagi korbannya.

\section{Karakteristik Luka Tusuk}

Pada luka tusuk, panjang luka pada kulit dapat sama, lebih kecil ataupun lebih besar dibandingkan dengan lebar pisau. Kebanyakan luka tusuk akan menganga bukan karena sifat benda yang masuk tetapi sebagai akibat elastisitas dari kulit. Pada bagian tertentu pada tubuh, dimana terdapat dasar berupa tulang atau serat otot, luka itu mungkin nampak berbentuk seperti kurva. Panjang luka penting diukur dengan cara merapatkan kedua tepi luka sebab itu akan mewakili lebar alat. Panjang luka di permukaan kulit tampak lebih kecil dari lebar alat, apalagi bila luka melintang terhadap otot. Bila luka masuk dan keluar melalui alur yang sama maka lebar luka sama dengan lebar alat. Tetapi sering yang terjadi lebar luka melebihi lebar alat kerena tarikan ke samping waktu menusuk dan waktu menarik. Demikian juga bila alat/pisau yang masuk kejaringan dengan posisi yang miring.

Bentuk dan ukuran dari luka tusuk di kulit tergantung pada jenis pisau, arah dorong, gerakan pisau saat menusuk, pergerakan korban saat ditusuk, dan keadaan elastisitas kulit. Ketajaman alat dapat menentukan batas luka, tepinya dapat tajam dan teratur, kulit terkelupas, memar ataupun bergerigi. ${ }^{11}$

Luka tusukan pada kepala dan leher jarang terjadi. Luka tusuk pada leher dapat menyebabkan kematian yang cepat oleh karena perdarahan, emboli udara atau asfiksia yang disebabkan karena perdarahan jaringan lunak yang hebat dengan tekanan kompresi di trakea dan pembuluh darah di leher. ${ }^{12}$

Luka tusukan yang paling bahaya terletak di daerah dada kiri. Seseorang akan cenderung menusuk dada sebelah kiri. Selain itu, jika seseorang berniat untuk membunuh maka orang tersebut akan menusuk pada dada sebelah kiri, hal ini karena sebagaian besar jantung terletak di dada sebelah kiri sehingga orang tersebut berfikir korban akan lebih cepat mati. ${ }^{12}$

Luka tusukan pada tulang belakang juga jarang ditemui. Seperti pada luka tusukan kepala, pisau yang digunakan dapat pecah dan ditemukan pecahannya di tulang belakang. Cedera pada medula spinalis dapat menyebabkan kelumpuhan.

Luka tusuk pada bagian abdomen dapat menimbulkan kerusakan pada hepar, lien, gaster, pankreas, renal, vesika urinaria, usus sehingga dapat menimbulkan perdarahan yang cukup banyak. Luka tusuk lebih sering terjadi pada kuadran atas dari abdomen dibandingkan dengan kuadran bawah. Kematian tidak terjadi secara langsung pada luka tusuk di abdomen. Faktanya baru beberapa hari bahkan sampai beberapa minggu luka tusuk dapat menyebabkan kematian. ${ }^{12}$ 


\section{Karakteristik Luka Iris}

Ciri utama luka iris dibanding luka akibat benda tajam lainnya adalah panjangnya melebihi kedalamannya, sebab terjadi akibat tekanan ringan benda tajam sewaktu digeserkan pada permukaan kulit. Dengan demikian panjang dan dalam luka iris sama sekali tidak menginformasikan ukuran benda tajam penyebab. Luka iris berukuran $3 \mathrm{~cm}$ bisa saja diakibatkan oleh pisau dapur berukuran $6 \mathrm{~cm}$, pisau cukur berukuran $2 \mathrm{~cm}$, atau bahkan sepotong pecahan kaca. ${ }^{13}$

\section{Karakteristik Luka Bacok}

Luka bacok disebabkan oleh alat instrumen berat senjata yang mempunyai setidaknya satu sisi yang tajam, contohnya seperti kapak, pemotong daging dan parang. ${ }^{14}$

1. Luka bacok terdiri dari luka iris yang memiliki alur atau potongan pada dasar tulang.

2. Jika arah bacokan melingkar, maka bagian yang terkena berbentuk seperti piringan yang terpotong pada tulang atau jaringan lunak sekitarnya.

3. Tepi yang tumpul pada senjata bacok (seperti sekop) bisa menyebabkan lebih banyak remukan daripada irisan pada jaringan yang menghasilkan luka yang lebih konsisten ke arah robekan daripada luka irisan.

4. Baling-baling yang bergerak (kapal atau pesawat) bisa menyebabkan luka bacok yang lebih parah.

5. Adanya jaringan lunak yang disertai hemoragik dengan luka bacok atau luka iris secara umum dianggap sebagai bukti yang baik, bahwa luka timbul sebelum kematian. Tubuh yang terendam lebih lama didalam air bisa menyebabkan hemoragik yang pada awalnya ada di luka lebih memudar, dan menyebabkan tampilan penyebab kematian yang sulit ditemukan.

\section{SIMPULAN}

Berdasarkan hasil penelitian pola luka pada kematian akibat kekerasan tajam di Bagian Ilmu Kedokteran Forensik dan Medikolegal RSUP. Prof. Dr. R. D.
Kandou Manado periode 2013 dapat disimpulkan bahwa dari jenis luka yang sering terjadi pada kekerasan tajam (luka tusuk, luka iris dan luka bacok), yang tersering ialah luka tusuk. Usia korban tersering pada kelompok umur 20-30 tahun. Kekerasan yang terjadi biasanya mengakibatkan beberapa luka pada satu orang korban. Kekerasan tajam sering terjadi pada bagian dada kiri, jantung dan lengan kiri.

\section{SARAN}

1. Sarana dan prasarana lebih ditingkatkan demi menunjang kepastian data yang akan diteliti.

2. Mengedukasi pentingnya tindakan untuk melaporkan sedini munngkin kasus kekerasan tajam yang terjadi.

3. Meningkatkan dan memperhatikan dengan teliti kasus kekerasan tajam yang terjadi, terutama pada kelompok umur muda.

\section{DAFTAR PUSTAKA}

1. Abdussalam HR, Desasfuyanto A. Buku Pintar Forensik. Jakarta: PTIK PRESS, 2014.

2. Liputan 716 September 2014. Provokator Menyebar, Eskalasi Keamanan di Manado Terancam. [cited 2014 Sept 17]. Available from: Liputan7.com: http://liputan7.com/2014/09/provokator -menyebar-eskalasi-keamanan-dimanado-terancam.html

3. Manado Post Online 12 Juli 2014. Kasus Sajam di Manado "Mencekam". [cited 2014 Sept 17]. Available from: manadopostonline.com:

http://manadopostonline.com/read/2014 /07/12/Kasus-Sajam-di-ManadoMencekam/4039

4. Swara Manado Online 6 Agustus 2014. Penganiayaan dan Kasus Sajam di Sulut Meningkat. [cited 2014 Sept 17]. Available from: swaramanadoonline.com: http://www.swaramanadoonline.com/2014/08/penganiayaan-dankasus-sajam-di-sulut.html.

5. Bibliography Manado Tribun News Online 11 September 2013. Kasus Sajam Dominan Orang Muda. [cited 2014 
Nerchan, Mallo, Mallo: Pola luka pada kematian akibat kekerasan tajam ...

Sept 17]. Available from: manado.tribunnews.com:

http://manado.tribunnews.com/2013/09/

11/kasus-sajam-dominan-orang-muda

6. Budiyanto A, Widiatmaka W, Sudiono S, Mun'im TWA, Sidhi, Hertian S, et al. Ilmu Kedokteran Forensik. Jakarta: Bagian Kdokteran Forensik FKUI, 1997.

7. Idries AM, Tjiptomartono A. Penerapan Ilmu Kedokteran Forensik dalam Proses Penyidikan. Jakarta: Sagung Seto.

8. Ashari I. Luka Tembak (online). [cited 2014 Dec 11]. Available from: Hyperlink http://www.irwanashari.com/lukatembak/

9. Syaulia, Andirezeki, Wongso (online). [cited 2014 Dec 11]. Available from: http://www.scribd.com/document_dow nloads/direct $/ 54671022$ ?extension=doc

$\mathrm{x} \& \mathrm{ft}=1318157772 \& \mathrm{lt}=1318161382 \& u a$ $\mathrm{hk}=\mathrm{qEAJ} 2 W P V q 8 f 0 \mathrm{hXZUvyZXXK08}$ 2

10. Forensic Pathology (online). [cited 2014 Dec 11]. Available from: Hyperlink http://library.med.utah.edu/WebPath/ FORHTML/FOR039.html

11. DiMaio VJ, DiMaio D. Forensic Pathology (2nd ed.). London: CRC Press LLC, 2001.

12. Referat Luka Tusuk (online). [cited 2014

Dec 11]. Available from: http://www.scribd.com/doc/236790233/ Referat-LUKA-TUSUK-ForensikEditan-Tice

13. Luka Iris dan Luka Tusuk (online). [cited 2014 Dec 11]. Available from: http://www.scribd.com/doc/132211998/ Luka-Iris-Dan-Luka-Tusuk

14. DiMaio VJM, Danna ES. Handbook of Forensic Pathology (2nd ed.), 2006. 